\title{
An Environmental Perspective of Dracunculiasis and the Guinea Worm Eradication Programme on Human Behaviour in the Northern Region of Ghana
}

\author{
Nicholas N-Kang Yembilah ${ }^{1}$ \\ ${ }^{1}$ Simon Diedong Dombo University of Business and Integrated Development Studies, Ghana \\ Correspondence: Nicholas N-Kang Yembilah, Simon Diedong Dombo University of Business and Integrated \\ Development Studies, Ghana.
}

Received: January 18, 2021 Accepted: March 28, 2021 Online Published: March 31, 2021

\begin{abstract}
This article examines the role dracunculiasis (Guinea Worm Disease - GWD) and the Guinea Worm Eradication Programme (GWEP) played in changing community members' behaviour towards the disease and their biophysical environment. The research design that was used to collect data was the mixed method approach, in which questionnaire was administered, Focus Group Discussion (FGD) was held, and key informant interviews conducted. Krejcie and Morgan's formula for determining sample population for research was used to determine the sample population of the study area, which was 860 . It was found that bedrock lithology made community members to resort to unsafe sources of drinking water which exposed them to GWD. It was also realized that the educational programmes which the GWEP brought along with it changed community members' behaviour towards their bio-physical environment, which ultimately resulted in eradicating the disease in the study area. It was therefore recommended that in carrying out disease eradication or control programmes, the environmental protection agency should be involved in the process of educating community members on methods of improving on the integrity of their natural and built environment to enhance the overall health status of the community.
\end{abstract}

Keywords: dracunculiasis, guinea worm eradication programme, human behaviour, environment

\section{Introduction}

Guinea Worm Disease (GWD), scientifically known as Dracunculiasis, was reported in Ghana by Waddy (1956). However, it was not until the early to mid-1980s that efforts were made to eradicate it (CDC-Wrap-Up No. 18, 1987). Since Guinea worm is a waterborne disease, some aspects of marine and vegetal environments were variously affected during the epidemic (Hunter, 2003; Hochkirch et al., 2017).During this period the disease had varying effects not only on health, but also on human behaviour towards the environment (Dietz et al., 2013). In the Northern Region of Ghana in which the disease was most prevalent (CDC-Wrap-Up \#20, 1988; Wrap-Up Nos. 23-26, 1989; Wrap-Up No. 27, 1990), it affected most aspects of peoples' behaviour towards the disease and their bio-physical environment. (CDC- Wrap-Up No. 19, 1988; Greenwood et al., 2017; Hochkirch et al., 2017). This drew attention to the effects of the disease on humans and their behaviour towards the environment (CDC- WrapUp No. 12, 1986; Greenwood et al., 2017). This gave rise to the need for the Guinea Worm Eradication Programme (GWEP) to intervene and eradicate the disease and also change human behaviour towards the bio-physical environment of affected communities. This paper therefore examines the ways in which GWD and the GWEP changed people's behaviour towards the disease and the bio-physical environment in which they live and work.

\section{Methodology}

\subsection{Study Design and Sampling}

Recognizing that qualitative and quantitative methods have limitations, the mixed method approach (combining qualitative and quantitative methods) was used to collect data from the administrative districts of the Northern Region which were defined to be guinea worm endemic districts. This was to neutralize the effect of or cancel out biases inherent in each method and to integrate quantitative data with qualitative data (supporting statistical results with qualitative quotes) to make results from both methods to reinforce each other (Creswell, 2009). Therefore questionnaire surveys and Focus Group Discussions (FGDs) was administered to respondents in the study area. Key informant interviews were held with selected community members in each district. This was to obtain first- 
hand information on the effects of the guinea worm epidemic and the GWEP on human behaviour towards aquatic habitats from which drinking water was obtained and their surrounding vegetal environments.

\subsection{Data Collection and Analysis}

The adult population of the region, which is between the ages 15 and $60+$ was estimated by the Ghana Statistical Service to be $61.7 \%$ of the region's population. The sample population for the study was determined by using the adult population of the region to extract the adult population for the study area from the 2010 Population and Housing Census record for the study area. The population was 1, 137, 244 (GSS, 2013). The adult population which is $61.7 \%$ of the study area was therefore put at 701680 . Krejcie and Morgan's (1970) work on Determining Sample Size for Research Activities was used to determine the sample population for the study area. The ideal sample size for a population of 1000000 is 348 . Therefore the ideal sample population of the study area was 270 . However, considering the fact that some districts would have very low proportionate sample sizes for the study area, adjustments were made to the proportionate sample sizes for each district to achieve a sufficient representation of respondents for each district. The adjustments made for each district's sample size resulted in the study area having a sample population of 860 respondents.

Data was collected from 11 administrative districts which were defined as guinea worm endemic areas. Primary data was obtained from respondents who were categorized into Household heads and Opinion leaders. The categories were necessary because household heads are mostly farmers and domestic hands and were considered to be those who were directly involved in interacting with their aquatic and vegetal environments and so adopted coping strategies during the epidemic and the programme which affected their environment in one way or the other. Residents were in this category of respondents because the epidemic directly or indirectly affected other community members who did not fall victim to guinea worm infection. Opinion leaders were consulted because they are considered to belong to a category of people who could share their life experience of the epidemic and the role the programme has played in restoring sanity to their environment. Respondents were proportionately distributed among the districts according to the respective populations of each districts and were randomly selected and interviewed. Table 1 shows the study districts and the number of respondents selected for each district (GGWEP/GHS, 2012).

Table 1. Sample population of the study area

\begin{tabular}{lcccc}
\hline District & Household head & $\begin{array}{c}\text { Opinion } \\
\text { Leaders }\end{array}$ & Total & Percent \\
\hline Yendi & 128 & 27 & 155 & 18 \\
Savelugu-Nanton & 80 & 15 & 95 & 11 \\
East Gonja & 82 & 12 & 94 & 11.2 \\
Central Gonja & 49 & 9 & 58 & 6.7 \\
Zabzugu-Tatale & 73 & 15 & 88 & 10.2 \\
Nanumba North & 41 & 8 & 49 & 5.7 \\
Nanumba South & 64 & 9 & 73 & 8.4 \\
Gushiegu & 59 & 11 & 70 & 8.2 \\
Karaga & 58 & 8 & 66 & 7.6 \\
Tolon & 39 & 6 & 45 & 5.2 \\
Kumbungu & 59 & 8 & 67 & 7.8 \\
\hline Total & & & $\mathbf{8 6 0}$ & $\mathbf{1 0 0}$ \\
\hline
\end{tabular}

Source: Field survey, October 2019-January 2020 
Key Informant interviews were held with selected community members to unearth how sources of drinking water and their surrounding vegetal environments was affected by the disease and how GWEP contributed to altering human behaviour towards their sources of drinking water and their surrounding environment. Focus Group Discussions were held with 22 focus groups. Every district had 2 groups, one for males and one for females. The purpose of these groups was to reduce gender related biases from each group.

Secondary data on sources of drinking water which influenced people behaviour towards the environment was classified under the following headings: pipe borne, borehole, well, dam, dugout, lagoon, river, rainwater, spring, and canal (GSS, 2008-2017). These sources were further classified into the following categories: potable and unpotable sources of drinking water. Dams, ponds, dugouts, rivers, springs and rain water were considered unpotable sources of drinking water. Water from pipes, boreholes, and wells were considered potable sources of drinking water. Wells were potable sources because they are owned by individuals and are found within the precincts of the homes of individuals who owned them and have concrete enclosures at their mouths to prevent pollutants from entering them. Data was presented with tables, maps, graphs and simple statistics.

\section{Results and Discussion}

\subsection{Demographic Characteristics of Respondents}

Some 860 respondents comprising $85.12 \%$ (732) household heads and 14.88\% (128) opinion leaders were interviewed. The strategy of enquiry being the mixed method obtained responses in both close and open ended form. Responses were entered on SPSSv20 to generate the results discussed below.

Table 2. Demographic characteristics of respondents

\begin{tabular}{|c|c|c|}
\hline $\begin{array}{l}\text { Demographic } \\
\text { characteristics }\end{array}$ & Number of respondents & Per cent \\
\hline \multicolumn{3}{|l|}{ Age } \\
\hline$>20$ & 40 & 5.7 \\
\hline $20-29$ & 191 & 22.2 \\
\hline $30-39$ & 251 & 29.2 \\
\hline $40-49$ & 174 & 20.2 \\
\hline $50-59$ & 104 & 12.1 \\
\hline $60+$ & 84 & 9.8 \\
\hline Don't know & 16 & 0.8 \\
\hline Total & 860 & 100 \\
\hline \multicolumn{3}{|l|}{ Sex } \\
\hline Male & 611 & 71 \\
\hline Female & 249 & 29 \\
\hline Total & 860 & 100 \\
\hline \multicolumn{3}{|l|}{ Education } \\
\hline Not gone to school & 650 & 75.6 \\
\hline Non-formal & 5 & 0.6 \\
\hline Formal & 205 & 23.9 \\
\hline Total & 860 & 100.1 \\
\hline \multicolumn{3}{|l|}{ Occupation } \\
\hline Farming & 586 & 68.1 \\
\hline Trader & 171 & 19.1 \\
\hline Formal sector & 80 & 9.3 \\
\hline Unemployed & 22 & 2.5 \\
\hline Total & 860 & 99 \\
\hline
\end{tabular}

Source: Field Survey, October 2019-January 2020

From Table 2, the demographic characteristics of respondents revealed that most respondents were the active population $(29.2 \%)$ and were male (71\%). By level of education $75.6 \%$ did not attend school and were mostly 
engaged in farming (68.1\%). This indicated that respondents were mostly the rural poor who depend primarily on the environment to earn a living. Also, in their study on Human behaviour, demography, and paleo environment on the Colorado plateaus, Dean, Euler, Gumerman and Plog (1985) noted that population in this environment experienced periods of regional population-resource stress which elicited behavioural responses which ranged from adaptive contributions of mobility, through shift of settlement location, to subsistence mix, and agricultural intensification among others. They indicated that these responses were triggered by environmental variability stimulated by demographic and sociocultural factors. Similarly, this paper anticipates that the demographic profile of respondents influenced respondents' behaviour towards their environment during the time GWD was prevalent and during the intervention period of the GWEP.

\subsection{Sources of Drinking Water}

Sources of drinking water in districts of the northern region that were endemic to GWD include: pipe borne water, boreholes, wells, rainwater, and surface sources of drinking water (dams, rivers/stream, and dugouts). The major source of drinking water in the guinea worm endemic districts was surface sources, with an average regional dependence of $75.6 \%$. This was followed by wells, accounting for an average regional dependence of $16 \%$. Pipe borne water was third with an average regional dependence of $6.3 \%$. Borehole and rainwater had the least average regional dependencies of $2.5 \%$ and $1.2 \%$ respectively. Residents of these districts did not practice a sophisticated regime of fetching water from surface sources, and water from potable sources (pipe borne water, boreholes, and wells) during the guinea worm epidemic was woefully inadequate (See Figure 1).

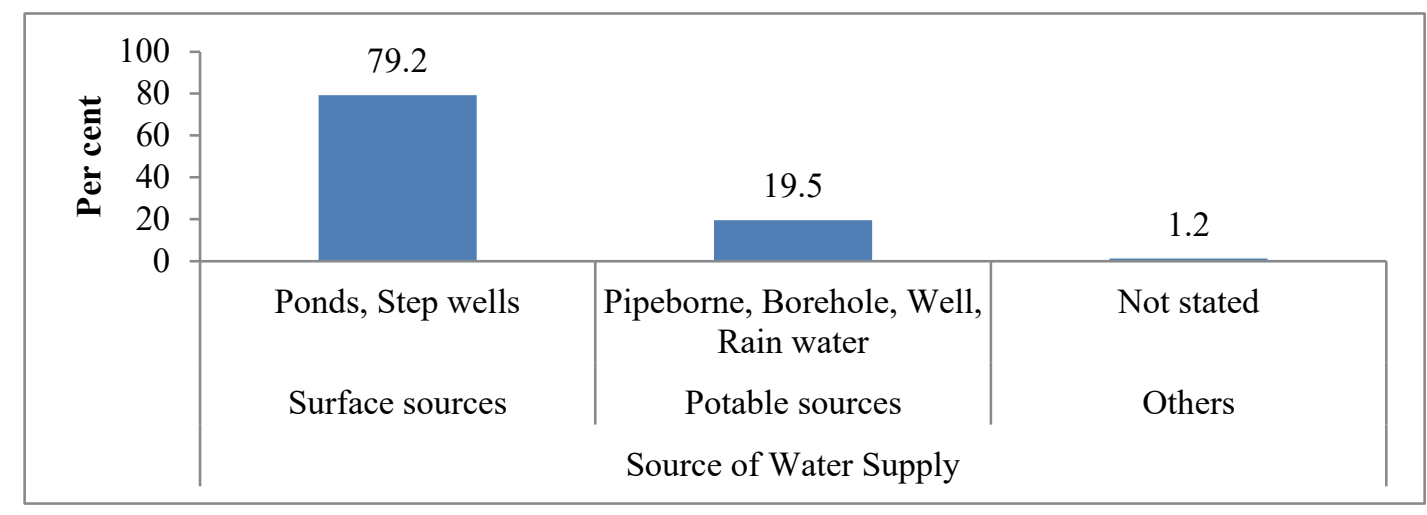

Figure 1. Sources of drinking water in guinea worm endemic area, Northern Region - 1984

Source: Ghana Statistical Service, 1984

It was observed that the major source of drinking water in the guinea worm endemic districts of the Northern Region of Ghana during the pre-eradication period was surface sources of water supply. The sources of drinking water were dams, dugouts, ponds, step wells, springs, rivers, and canals. Despite this disadvantage these districts had some sources of potable water. Potable water was provided through boreholes, wells, and stand pipes. During the pre-eradication period it was possible to come across broken down boreholes that took time to restore. Also piped borne sources of drinking water which came in the form of town and community standpipes were known to flow on specific days of the week and for a given time period. It was common practice during those days for taps to flow between $4 \mathrm{am}$ and $9 \mathrm{am}$. This meant, households did not always have sufficient water, especially during the dry season when the supply of water through standpipes was irregular. This left people with only one source of potable water during the dry season. This was water from wells. The level of wells during the dry season were known to drop so low to drying point because the rate of drawing water from them exceeded their capacities to replenish themselves. In the wake of this cycle of periodic abundance and scarcity of potable water between the wet and dry seasons it was quite easy to understand why people in towns and villages of guinea worm endemic districts were caught in a web of relying on unsafe sources of drinking water.

Surface sources of drinking water which include dams, ponds, dugouts, step-wells, and rivers was the major source of water supply for communities in guinea worm endemic areas of the Northern Region of Ghana before the GWEP was launched in 1989. It was this source of water supply that exposed people in guinea worm endemic districts to the biophysical agent of the disease. 


\subsection{Environmental Perspective of GWD}

Some environmental influences contributed to the occurrence of the disease in the former guinea worm endemic areas of the Northern Region. An interview granted by a key informant threw light on the role the environment played to sustain the presence of the disease in communities that were endemic to the disease. The first National Guinea Worm Coordinator who also served as a Director of Public Health Division (Monthly Epidemiological Bulletin, July 2010), indicated that environmental influences that accounted for the presence of the disease in the endemic districts of the Northern Region was that people relied more on surface sources of drinking water. Although some communities were provided with boreholes they preferred water from surface sources because drinking water from their boreholes was salty. Also, the practice of wading to knee-deep level to draw water from surface sources predisposed people to polluting their source of drinking water resulting in the spread of GWD.

It was explained during the interview that the Nanumba North and Nanumba South districts and parts of the Zabzugu Tatale district which are located in the south eastern corner of the region were exposed to the disease because their major source of drinking water during the epidemic was surface sources. There were few wells in these areas. The success rate for digging wells and drilling boreholes was very low. Access to underground water was difficult because water tables were so low as to render the digging of wells and drilling boreholes unproductive. The situation was explained by Gill (1969), Carrier, Aubut, Lefebvre, Racicot, Asare, Fontaine, and Rivera (2009), Agyekum (2004), and Acheampong (1998) in separate hydrological studies of ground water availability in the Northern Region of Ghana.

Gill (1969) explained that hydrogeological provinces in Ghana influences ground water occurrence and availability. He observed that hydrogeological provinces in the Northern Region are the Voltain and the Precambrian Provinces. Table 3 shows these provinces with their dominant lithologies. These lithologies reveal that spatial variability and quality of ground water is influenced by each province (Carrier et al., 2008).

Table 3. Lithologies of geological provinces of the Northern Region, Ghana

\begin{tabular}{|c|c|c|c|}
\hline Province & System & Series & Dominant lithology \\
\hline \multirow[t]{5}{*}{$\begin{array}{l}\text { Voltain } \\
\text { Province }\end{array}$} & \multirow[t]{5}{*}{ Voltain System } & Upper Voltain & $\begin{array}{l}\text { Massive sandstone, conglomerate } \\
\text { with thin beds of shale and mudstone } \\
\text { locally }\end{array}$ \\
\hline & & \multirow[t]{2}{*}{ Middle Voltain } & $\begin{array}{l}\text { Obosum beds - mudstone, shale, } \\
\text { sandstone, conglomerate, some } \\
\text { limestone }\end{array}$ \\
\hline & & & $\begin{array}{l}\text { Oti beds }- \text { Arkose, sandstone, } \\
\text { conglomerate, mudstone, shale, } \\
\text { limestone }\end{array}$ \\
\hline & & Lower Voltain & $\begin{array}{l}\text { Basal quartz sandstone with pebbly } \\
\text { grits and grits }\end{array}$ \\
\hline & & Buem series & $\begin{array}{l}\text { Shale, sandstone, lava and full with } \\
\text { some limestone, grit, and } \\
\text { conglomerate }\end{array}$ \\
\hline \multirow{4}{*}{$\begin{array}{l}\text { Precambrian } \\
\text { Basement } \\
\text { Province }\end{array}$} & Tarkwaian System & $\begin{array}{l}\text { Huni, Tarkwa, Banket, } \\
\text { Kawere }\end{array}$ & $\begin{array}{l}\text { Sandstone, shale, conglomerate } \\
\text { quartzite, schist, phyllite }\end{array}$ \\
\hline & \multirow[t]{3}{*}{ Birimian System } & Granitoid intrusions & Mainly granite, granodiorite, gneiss \\
\hline & & Upper Birimian & $\begin{array}{l}\text { Metamorphosed tuff and lava } \\
\text { (andesitic basaltic) }\end{array}$ \\
\hline & & Lower Birimian & $\begin{array}{l}\text { Schist, phyllite, slate, with greywacke } \\
\text { and sandstone }\end{array}$ \\
\hline
\end{tabular}

Source: Carrier et al., 2008 \& Yembilah, 2015 
The Precambrian Province has low primary porosity and permeability. Productive areas of groundwater in the Precambrian province are located in the lower and upper parts of the rock. These rocks complement each other with respect to permeability and storage. Because of this ground water control and flow is a function of secondary porosity. The Birimian System is known to yield high quantities of groundwater (Carrier et al., 2008). Hand dug wells are used to reach water in shallow aquifers. A setback of these wells is that they do not yield water throughout the year. This caused people to turn to surface sources of drinking water during the lean season. This put pressure on the aquatic environment around which community members and livestock gathered during the lean season to get water. There were few cases where boreholes are drilled to depths of $35 \mathrm{M}$ to $62 \mathrm{M}$ in Birimian and Tarkwaian systems (Precambrian Basement Province) to get potable water throughout the year. (Agyekum, 2004).

Rocks of the Voltain Province are consolidated and impermeable. Ground water in this province occurs in fracture zones and along bedding planes. The primary porosity of these rocks got destroyed as a result of compacting of loose deposits into sedimentary rock. The Voltain system is unsaturated in many places and provides small amounts of ground water. (Acheampong, 1998). This is because the regolith of the Voltaian Province has stable compositions of clay (shale), quartz (sandstone), or soft unmetamorphosed mudstone which are able to store water. However, these rocks don not readily give up water. The productivity of aquifers of this province is low or at best moderate.

In contrast the middle Voltaian series has in its lithology arkose or arkosic sandstone (Oti beds) which it stores and readily gives up as ground water from shallow perched aquifers. These aquifers in some instances have been tapped with shallow hand dug wells. (Acheampong, 1998). Geological provinces with arkosic sandstones are a rare formation within the districts of the study area. (Yembilah, 2015). The formation of this lithological formation restricts peoples' options in the study area from obtaining ground water from shallow wells.

Because it is difficult to obtain water from the Upper Voltaian and parts of the Middle Voltaian series, borehole depths are deeper than the Precambrian series. Boreholes in the Voltaian series reach depths that are between 45 M to $75 \mathrm{M}$. (Agyekum, 2004). Also, low transmissivity and high resistivity made boreholes in this province to attain record depths of approximately 355 M. (Carrier et al., 2008).

The variability of borehole yields coupled with the low success of sighting potable water in the study area, made Acheampong and Hesse (1998) to indicate that "water bearing structures are discrete entities with highly variable production rates." This was the case with guinea worm endemic districts which are located mostly on Obosum beds of the Middle Voltaian series. These beds have high quantities of clay that prevents the flow of ground water. They are unsaturated in many areas and provide minor amounts of ground water, resulting in high failure rates when bore holes and wells are sunk in these districts. This situation made inhabitants of communities that were endemic to the disease to turn to surface sources for drinking water with its accompanying adverse effects on these sources of drinking water and their surrounding areas.

It was further noted during the interview that endemic districts in the Gonja area were provided with boreholes; but people preferred surface water to ground water because of the perception that ground water in these areas was salty. The people therefore preferred to rely on surface sources of water supply for their drinking water. The relationship between high saline content of ground water and the low primary porosity and permeability of the Obosum and Oti beds and Upper Voltain formation in these districts made residents of these areas to turn to surface sources of drinking water with its attendant adverse effects on dams, ponds, streams, water sheds and surrounding vegetation that are close to these sources of drinking water. Also, in endemic districts that are located in the Dagomba area the interviewee intimated that the "knee deep" culture of fetching water had some adverse effects on surface sources of drinking water and their surrounding environs.

\subsection{Behavioural Change Towards GWD and the Environment}

With the introduction of eradication measures, the GWEP brought about changes in the behaviour of residents in the study area which had some effects on their surface sources of drinking water and their surrounding environment Before the programme was implemented people in guinea worm endemic communities did not link their sources of drinking water to the disease, while the enlightened few could not prescribe a lasting solution to the problem. When the programme was implemented education on prevention and avoiding disease spread. Acquired knowledge on avoiding the disease had the added effect of changing peoples' behaviour towards their sources of drinking water and environments in which they live and work.

Respondents were asked to indicate if the programme has changed people's behaviour towards the disease, their sources of drinking water and the surrounding environments in which they live and work. Responses which were yes, no, and none were examined by district. 


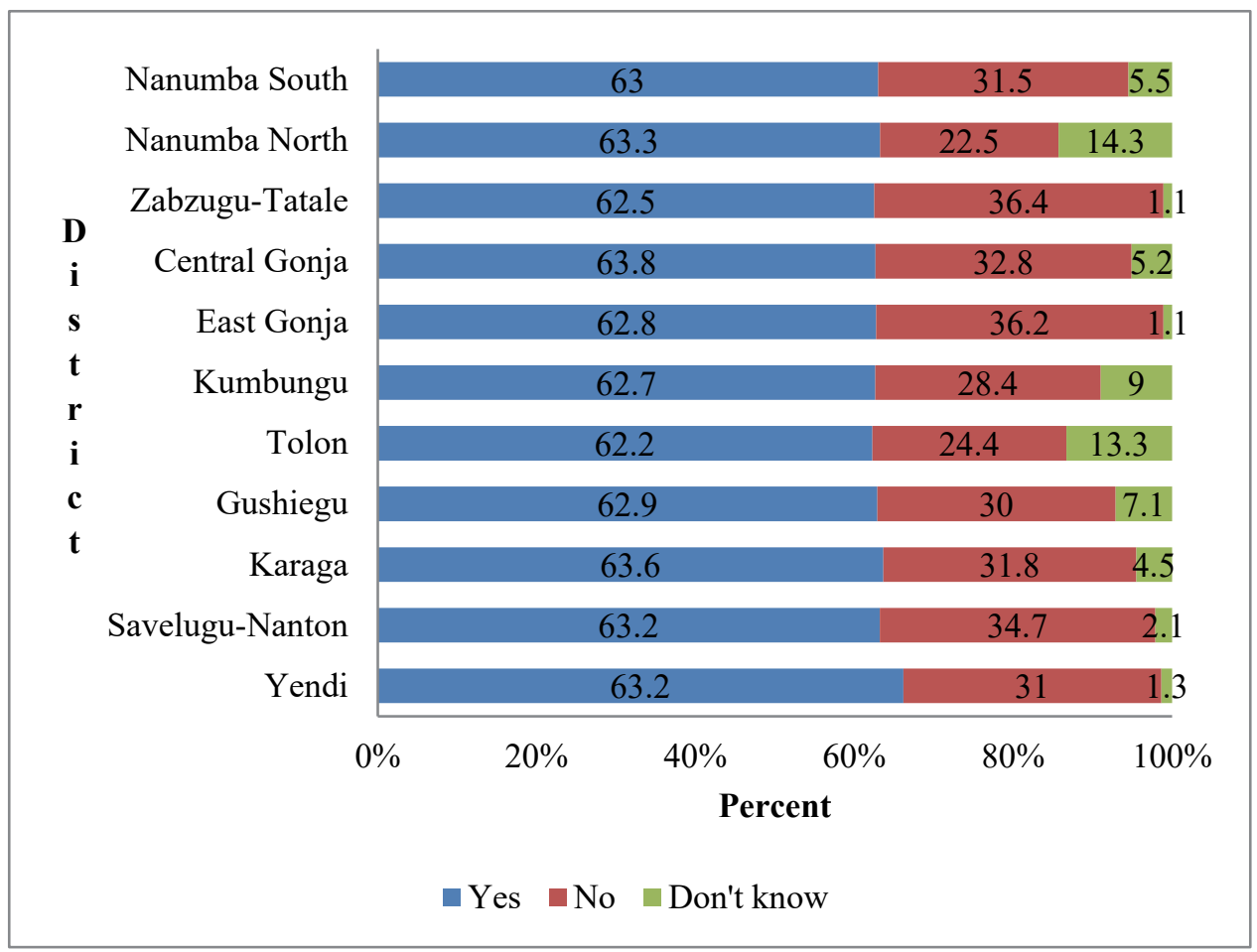

Figure 2. Behavioural change towards GWD and environment

Source: Field survey, October 2019-January 2020

In response to this question an average of $63 \%$ of respondents from the endemic districts indicated that the programme has changed people's behaviour towards the disease, their sources of drinking water and the surrounding environments in which they live and work. The remaining 30.9\% and 5.8\% said no and don't know respectively (see Figure 2).

During FGD most participants in the Dagomba areas of endemicity indicated that the programme affected people's behaviour towards the disease and their environment. They were followed by participants in the Gonja area. The Nanumba and Konkomba areas had few participants indicating that the programme affected peoples' behaviour towards the disease and their environment. There were some participants in all ethnic areas who felt the programme has not affected peoples' behaviour towards the disease and their environment. These participants were not as many as those who thought the programme had changed peoples' behaviour towards the disease and their environment.

Some participants noted that the programme should not be credited with any positive or negative change in behaviour towards the environment. They were of the opinion that paying attention to the environment was not one of the mandates of the programme. Any activity of the programme which affected the environment should be considered as one of the residual effects of the programme in the area. From these responses it was observed that the programme was thought to have brought attitudinal changes towards the use of surface sources of drinking water thereby improving the surrounding areas of surface sources of drinking water.

Table 4. Chi-square test on whether GWEP changed peoples' behaviour towards GWD and the environment

\begin{tabular}{cc}
\hline Variable & Significance Value \\
\hline Respondent Category & .227 \\
\hline Age & .004 \\
\hline Sex & .659 \\
\hline Education & .071 \\
\hline Occupation & .000 \\
\hline District & .000 \\
\hline
\end{tabular}

Source: Field survey, October 2019-January 2020 
A chi-square test at a significance level of 0.05 showed that the programme has changed people's behaviour towards the disease and their environment with respect to age, occupation, and district, with significance values of $.004, .000$ and, .000 respectively (See Table 4 ).

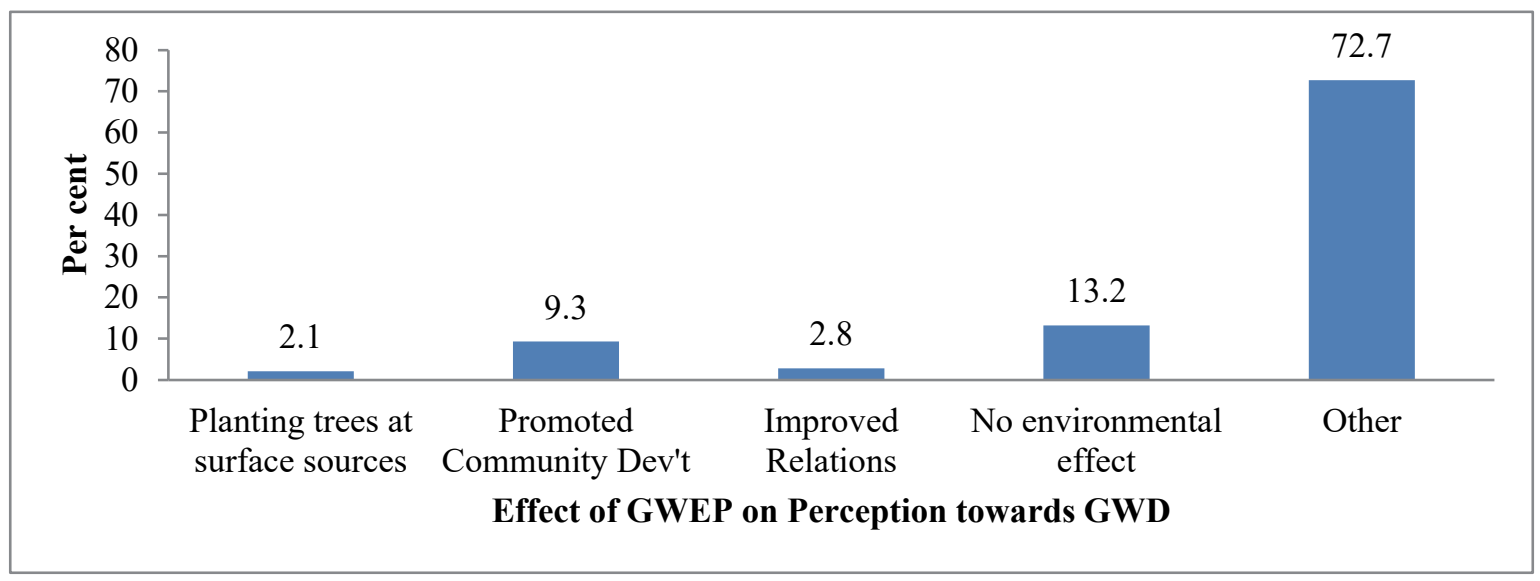

Figure 3. Changed behaviour towards environment

Source: Field survey, October 2019-January 2020

With regard to the programme changing peoples' behaviour towards the disease, $2.1 \%$ of respondents indicated that the programme made people plant trees close to surface sources of drinking water. Another $9 \%$ said the programme's activities paved the way for them to initiate community development projects. About $3 \%$ said interpersonal relations have been fostered among them. Another 13.2\% said they did not think the programme has achieved any remarkable change in people's behaviour towards the disease or the environment. The remaining $72 \%$ of respondents advanced no reason for the contribution of the programme in changing people's behaviour towards the disease (see Figure 3).

When examined respect to respondent category, it was found that $61.7 \%$ and $57.4 \%$ of opinion leaders and household heads/residents respectively were of the view that the programme has changed peoples' behaviour towards the disease because it influenced them the adopt good sanitation measures. Other effects the programme is said to have caused is planting trees $\mathrm{cl}$ 'ose to some surface sources of drinking water (see Figure 4).

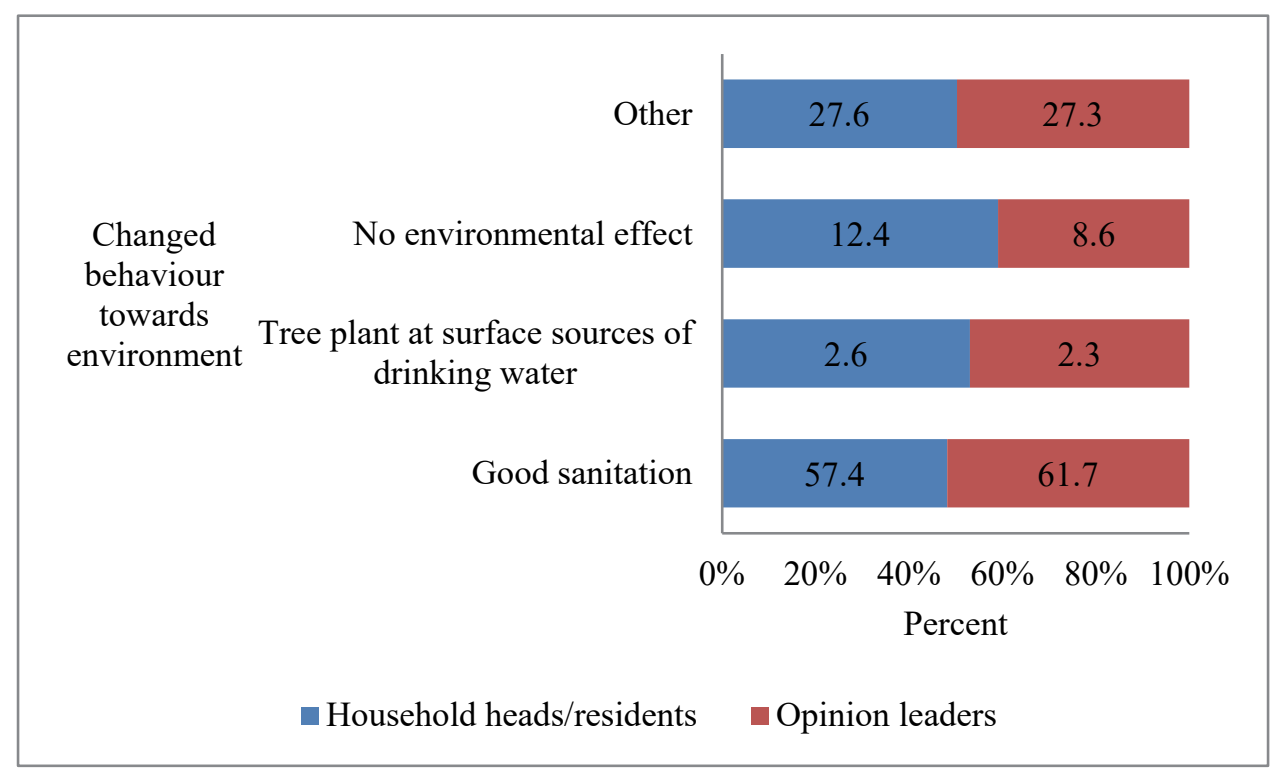

Figure 4. Changed behaviour towards environment by respondent category

Source: Field survey, October 2019-January 2020 
Change of behaviour by age showed that respondents in all age brackets were of the opinion that the programme caused change of behaviour in terms of good sanitation and planting trees close to surface sources of drinking water (see Figure 5).

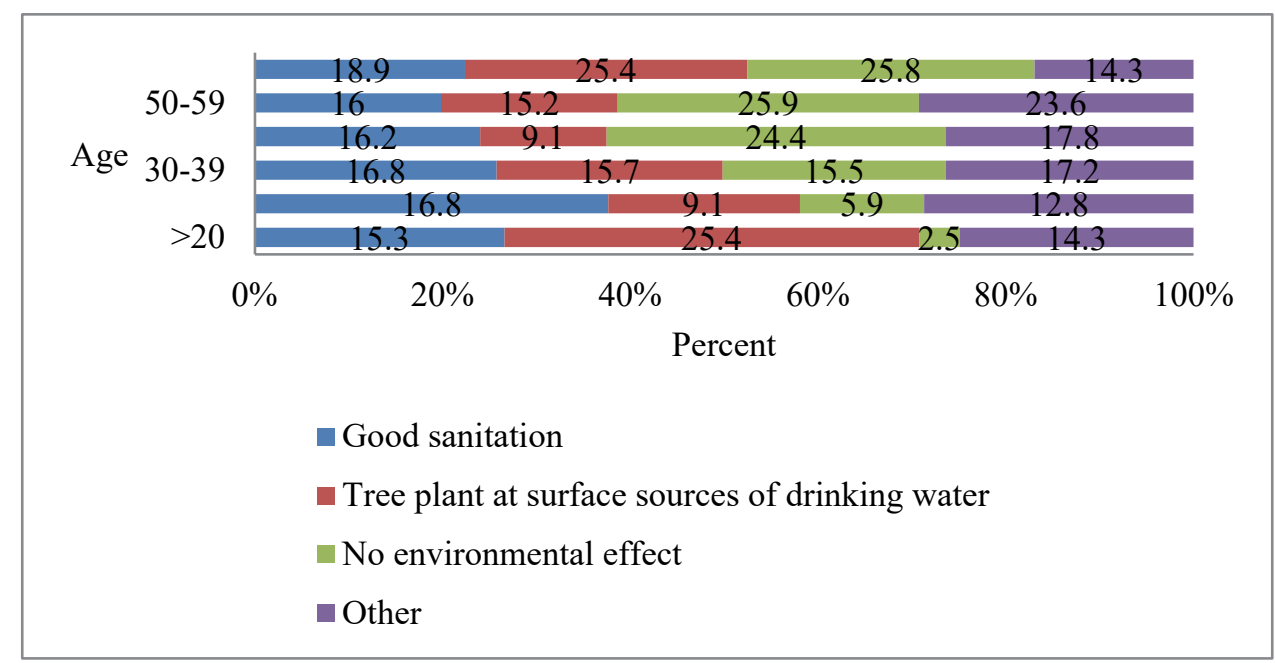

Figure 5. Changed behaviour towards environment by age

Source: Field Data, October 2019-January 2020

With regards to sex it was realised that $54.1 \%$ of males and $54.2 \%$ of females indicated that the programme changed peoples' behaviour towards the disease and the environment by making people to adopt good sanitation practices and planting trees near surface sources of drinking water (see Figure 6).

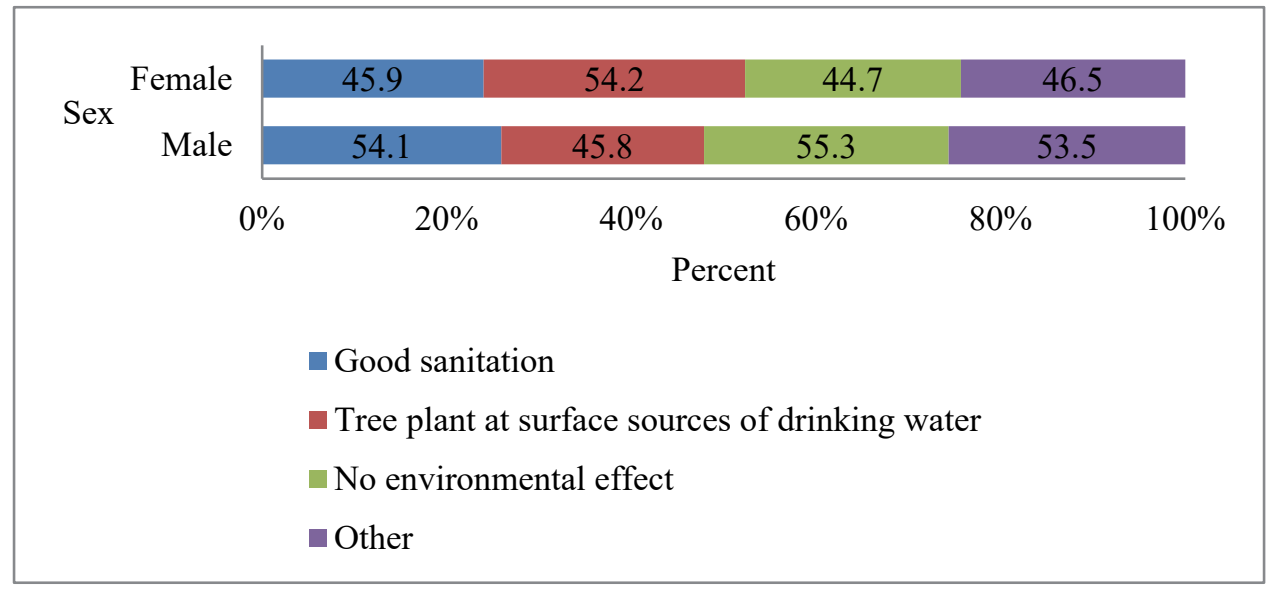

Figure 6. Changed behaviour towards environment by sex

Source: Field survey, October 2019-January 2020

It was observed in Figure 7 that respondents with non-formal education, formal education and those who have not had any form of education indicated that the programme changed peoples' behaviour towards the disease and the environment by making them to engage in good sanitation practices. In addition $68.1 \%$ with formal education constituted the majority of respondents who said the programme achieved behavioural change in the study area by encouraging the planting of trees near surface sources of drinking water. 


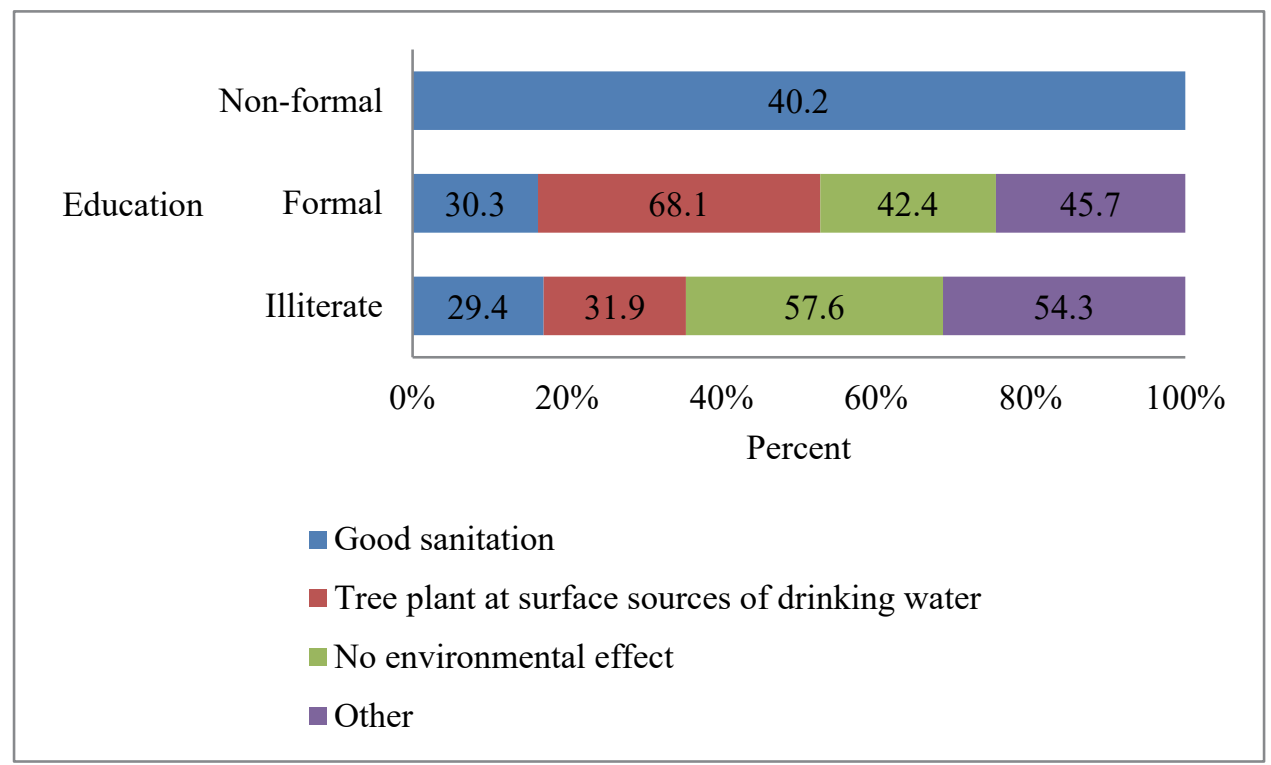

Figure 7. Changed behaviour towards environment by education

Source: Field survey, October 2019-January 2020

By occupation $57.9 \%$ of respondents indicated that the programme changed people's behaviour towards the disease by making them to engage in planting trees by surface sources of drinking water. Also, an average of $25 \%$ for all respondents for all occupational groups indicated that the programme changed people's behaviour towards the disease and the environment because community members were influenced to engage in good sanitation practices (see Figure 8).

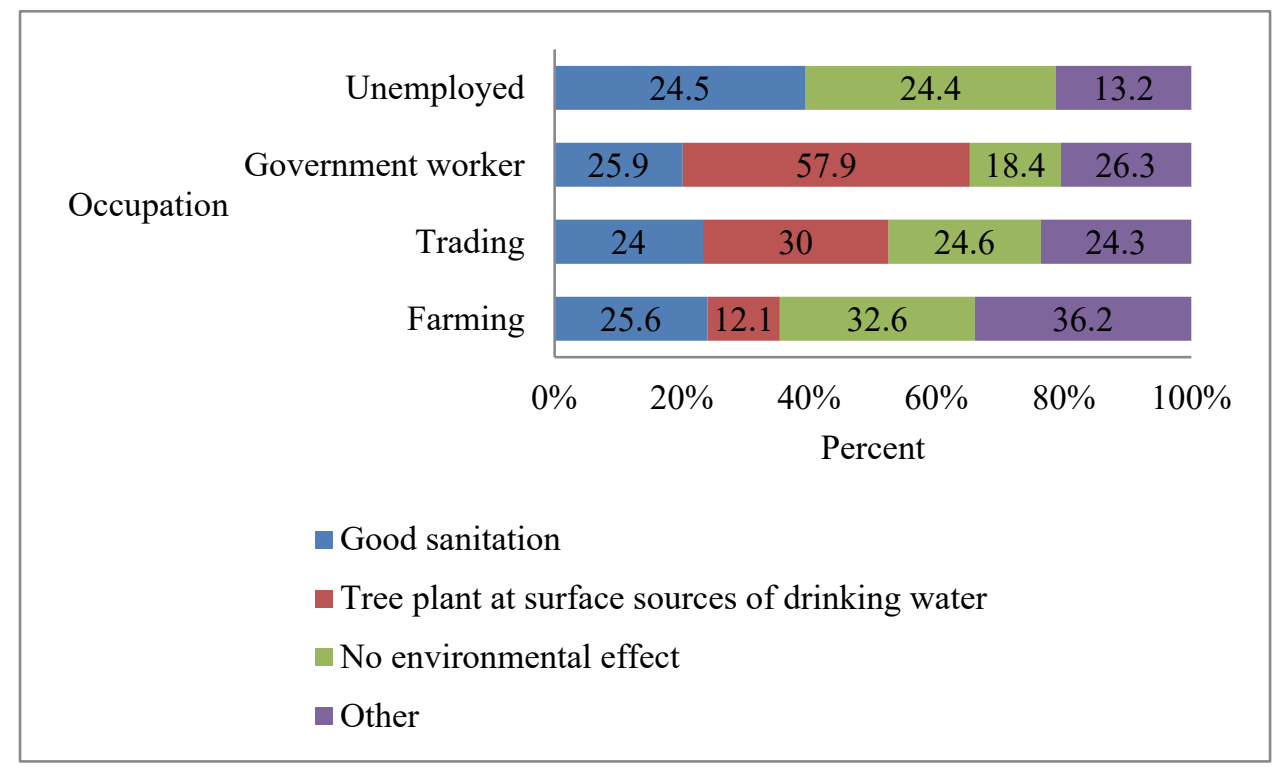

Figure 8. Changed behaviour towards environment by occupation

Source: Field survey, October 2019-January 2020

Changed behaviour towards the disease and the environment by district revealed that majority of respondents from Zabzugu-Tatale (12.5\%), Kumbungu (10.6\%), and Nanumba South (10.4\%) said the programme has changed their behaviour because they observe good sanitation practices around their homes and at surface sources of drinking water. With respect to planting trees near surface sources of drinking water only respondents from the Central 
Gonja district (100\%) indicated that the programme caused behavioural change because it influenced them to plant trees close to their surface sources of drinking water (see Figure 9).

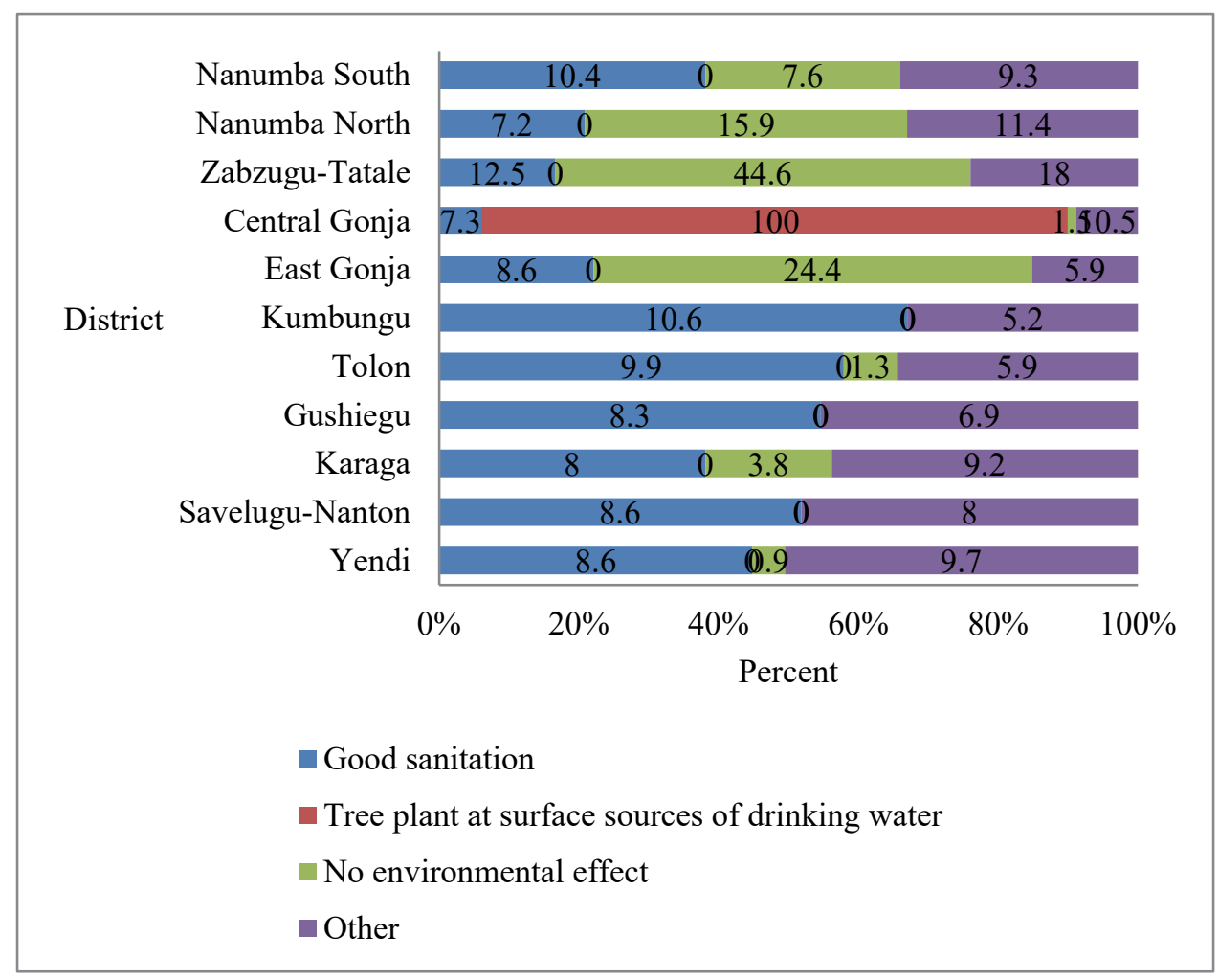

Figure 9. Changed behaviour towards environment by district

Source: Field survey, October 2019-January 2020

Table 5. Effect of GWEP peoples' behaviour towards the environment

\begin{tabular}{cc}
\hline Variable & Significance Value \\
\hline Respondent Category & .158 \\
\hline Age & .000 \\
\hline Sex & .294 \\
\hline Education & .366 \\
\hline Occupation & .007 \\
\hline District & .000 \\
\hline
\end{tabular}

Source: Field survey, October 2019-January 2020

Respondents' views were subjected to Pearson's Chi square test at a 0.05 significance level to determine which variables changed peoples' behaviour towards the disease. It was realized that age, occupation, and district with significance values of $.000, .007$ and, .000 respectively were the variables that strongly supported the view that the programme played a role in changing people's behaviour towards the disease and their environment (see Table $5)$.

From the above analysis it came to light that the GWEP revolutionized the way people in guinea worm endemic areas related towards the disease, which in turn had some beneficial effects on their surrounding environment. The solution to the problem was no longer a myth, but a reality which they were capable of handling on account of the knowledge the programme imparted to them. In the view of respondents, 
adherence to intervention measures of the programme was responsible for the following developments in the study area: improved sanitation, development of secondary forest, improved environment and unaffected environment, disturbed water bodies, undisturbed water bodies, and the creation of fire climax vegetal cover. The details of these responses are discussed below and shown in Figure 10.

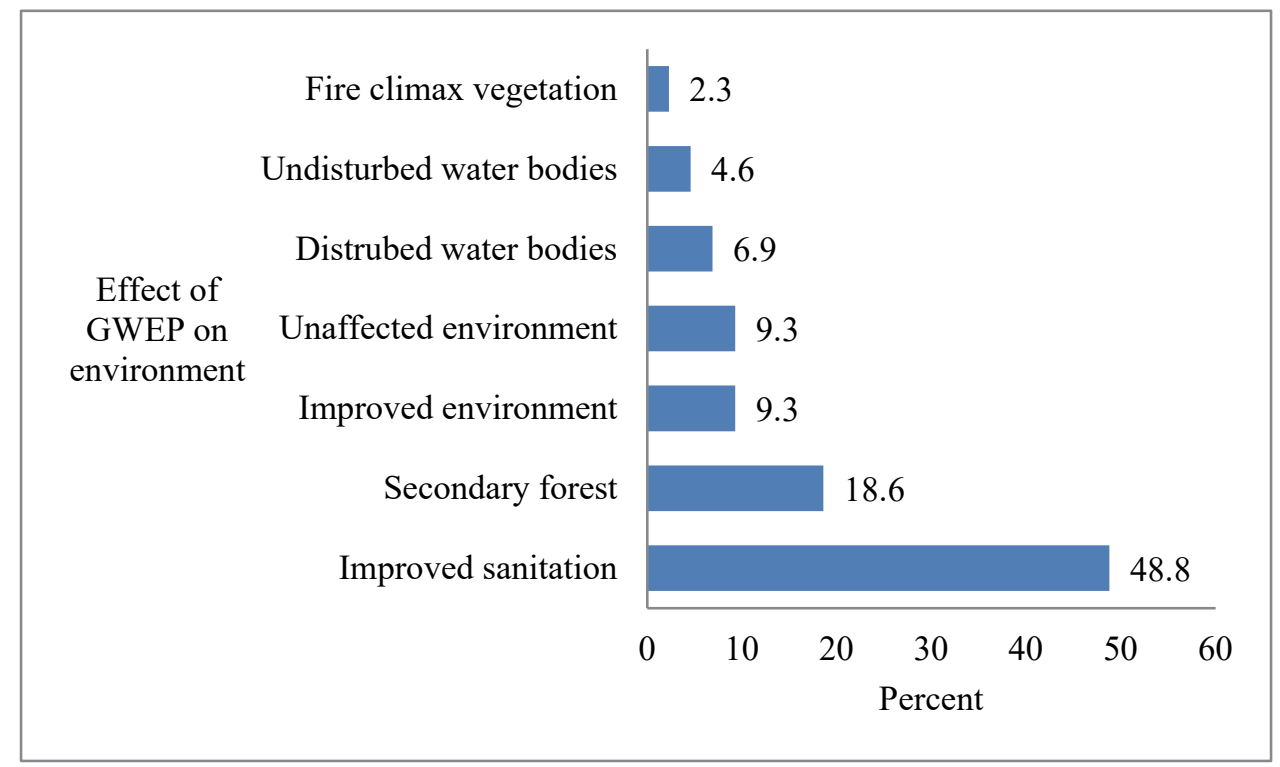

Figure 10. Effect of GWEP on the environment

Source: Field survey, October 2019-January 2020

\subsection{Improved Sanitation}

An environmental effect the programme had was that of a general improvement in sanitation, which was reported by $48.8 \%$ of respondents. These respondents explained that volunteers influenced community members to organise communal labour to regularly clean up their domestic surroundings and plant trees. Community members were encouraged by the programme to construct toilets and practice personal hygiene. The creation of stepping points at surface sources of drinking water to enable people avoid coming into direct contact with water has contributed in keeping the surrounding marine environment of surface sources of drinking water clean. The accompanying qualitative quotes on the programme's contribution to improve sanitation in former guinea worm endemic areas of the Northern Region illustrates respondents views on the programme's effect on people's behaviour towards the disease and the environment:

"The way the environment used to be dirty when the disease was there has now changed";

"Our communities make sure that conditions at our surface sources of drinking water are always kept clean;" and,

"Stepping points have been made at dams and ponds. We don't step into our surface sources of drinking water again."

This view was confirmed by Weiss et al., (2018) and Brieger et al., (1997) when they independently reported that the absence of GWD has changed the life style of people at the individual and community level not only in terms of health, but work which include household chores and villagers stressing the value of the programme in providing among other things increasing time available, especially for women, to engage in domestic activities respectively. In this regard Brieger et al., (1997) indicates in his work Eradicating guinea worm without wells: unrealized hopes of the water decade that because guinea worm is a water associated disease steps have been taken to provide clean accessible water and proper sanitation to communities through rural self-reliance with inter-sectoral collaboration.

\subsection{Development of Secondary Forest}

About $19 \%$ of respondents reported that the creation of secondary forests around their surface sources of drinking water was an effect the programme had on the environment of former guinea worm endemic areas of the study area. Climatic climax vegetal cover was destroyed by human activity. Vegetation that exist around surface sources of drinking water are comparatively young. They are considered to be the original trees that were destroyed by 
human activity. This vegetation became secondary forest. Respondents in this category indicated that volunteers were tasked to encourage tree planting around surface sources of drinking water. Community members were encouraged by volunteers to protect trees that grew within the vicinity of surface sources of drinking water. This initiative by volunteers and community members resulted in the surrounding environment around some surface sources of drinking water to have additional trees than they previously did. The development of secondary vegetation in response to disease was observed by Hunter (1966) in his article entitled River blindness in Nangodi, Northern Ghana: A hypothesis of cyclical advance and retreat. In it he pointed out that an area, once intensively farmed, got completely abandoned because of river blindness. This caused advancing woody vegetation to recolonize abandoned homesteads and farmlands. This was in response to river blindness. Similarly, respondents noted that the disease caused an environmental response when surface sources of drinking water were resorted to, to the point of exhaustion. And the programme elicited an environmental response by making community members to be less dependent on surface sources of drinking water, which has resulted in the surrounding woodlands and shrub lands to develop into secondary forest (Yembilah, 2015).

\subsection{Improved Environment and Unaffected Environment}

A little above $9 \%$ of respondents reported a general environmental improvement as one of the effects the programme had on their communities. Another $9.3 \%$ of respondents did not think there was some improvement in the environment of their communities. During FGDs respondents from the Zabzugu-Tatale district observed that the environment is still as good as it used to be before the programme started. Responses below illustrate respondents' perception of the programme's effect on the environment:

"The environment is good and, is better than the environment that existed before Guinea Worm

Eradication Programme was started;" and,

"The quality of our water bodies; our dams were regularly sprayed with chemicals."

Respondents who were of the view that the programme has not changed their environment in any way put up the following reasons to support their claim: "a good environment still exist; there is no effect in relation to our environment"; "our environment is still the way it used to be before the programme was brought;" and, "there is no change to our environment."

In his '... analysis of the guinea worm eradication programme and its effects on social and economic development in the Northern region of Ghana', Yembilah (2015) noted that some respondents did not think the programme has played any role in preserving or improving their environment. A respondent expressed this opinion by saying "the environment has not been affected in any way as a result of the programme".

\subsection{Disturbed Water Bodies}

Also, $7 \%$ of respondents indicated that the programme has adversely affected their environment because their surface sources of drinking water have been disturbed because the services of dam guards were withdrawn and the programme did nothing to stop it. This situation arose because more safe sources of drinking water have been provided in most areas thus making the need to rely on surface sources of drinking water unnecessary. Because of this a respondent said:

"Our water bodies are being destroyed and polluted again because the dam guards are no more there."

This concern was caused by decision makers who fail to consult with community members they serve. This could cause apathy and reversals in progress made in altering community members behaviour towards their environment and ultimately the disease. This was the case in Idere community in Nigeria where Volunteer Health Workers (VHW) associations produced, priced, promoted and distributed filters and influenced the raising of funds to construct concrete laden ring wells. But interference from government with respect to manufacturing and distributing filters, without consulting community member, caused a sense of lack of ownership in the distribution and education on the use of filters (Brieger et al., 1997).

\subsection{Undisturbed Water Bodies}

Additionally $4.7 \%$ of respondents claimed that the programme did not disturb their surface sources of drinking water. In their opinion they think their surface sources of drinking water "are now well protected and regularly cleaned." The response of water bodies being preserved was touched on by the Carter Centre which reported that a team of GWEP workers discovered an abandoned polyvinyl chloride pump in Nigeria and installed a new pump in place of the old one, resulting in residents who relied on the ponds within the vicinity of Etenyi no more resorting to the ponds for drinking water. Also the team in treating ponds with Abate in the area were asked by community 
members if the chemical will kill the fish in the ponds and were assured that, that would not happen (The Carter Centre, 2001-2002).

\subsection{Creation of Fire Climax Vegetation}

The remaining $2 \%$ of respondents commended the programme for arresting the situation of their vegetation being subjected to regular bush fires. Eradication of the disease eliminated the problem of disability, thus making it possible for people to protect their forests and bushes against indiscriminate bush burning. The following response describes the effect of the programme against indiscriminate bush burning:

"Our forests were regularly burned in the dry season and there were few people in the days of the disease to stop it; but now the situation has changed."

With the eradication of the disease people are healthy to take up various tasks including the protection of their forests. Plates 1, 2 and 3 show the effect of the programme on peoples' behaviour towards their environment. This situation was touched on when it was reported in the 1998-1999 Annual report of the Carter Centre that guinea worm was working against the building blocks (health, education and agriculture) of rural communities that had come under the scourge of the disease. By freeing these communities of the worm a big difference has been made in the lives of people. They are now able to stand on their own feet with respect to using their building blocks, including being healthy to prevent their wood and shrub lands from being destroyed.

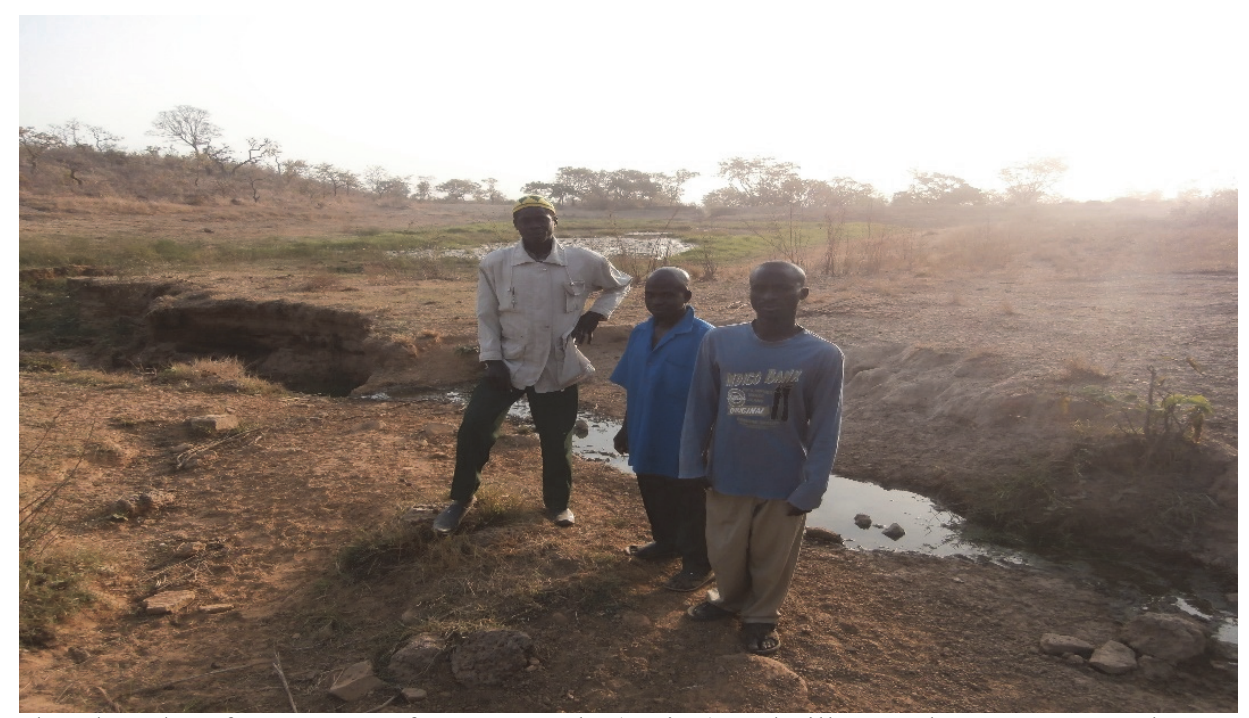

Plate 1. Abandoned surface source of water supply (spring) and village volunteers, Nasamba, Nanumba South District

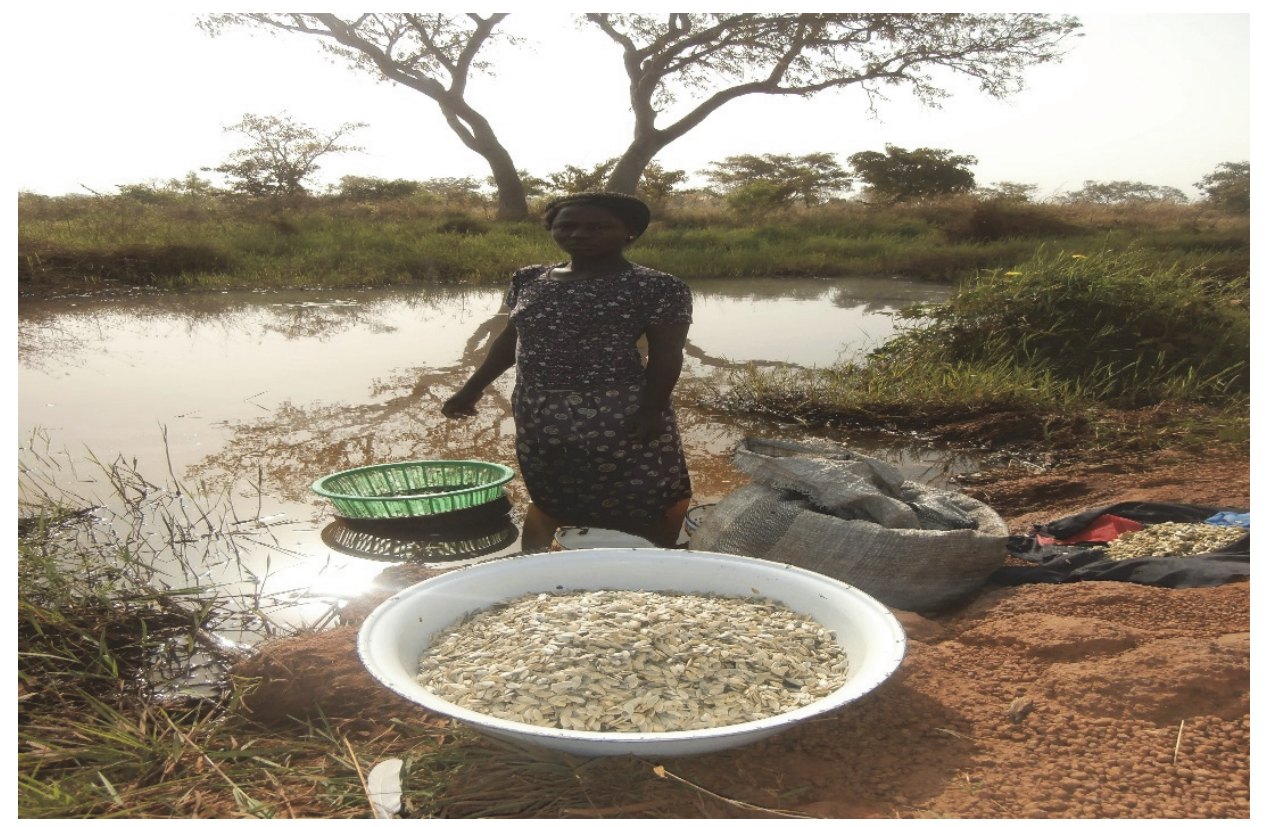


Plate 2. Continued dependence on surface sources of water supply

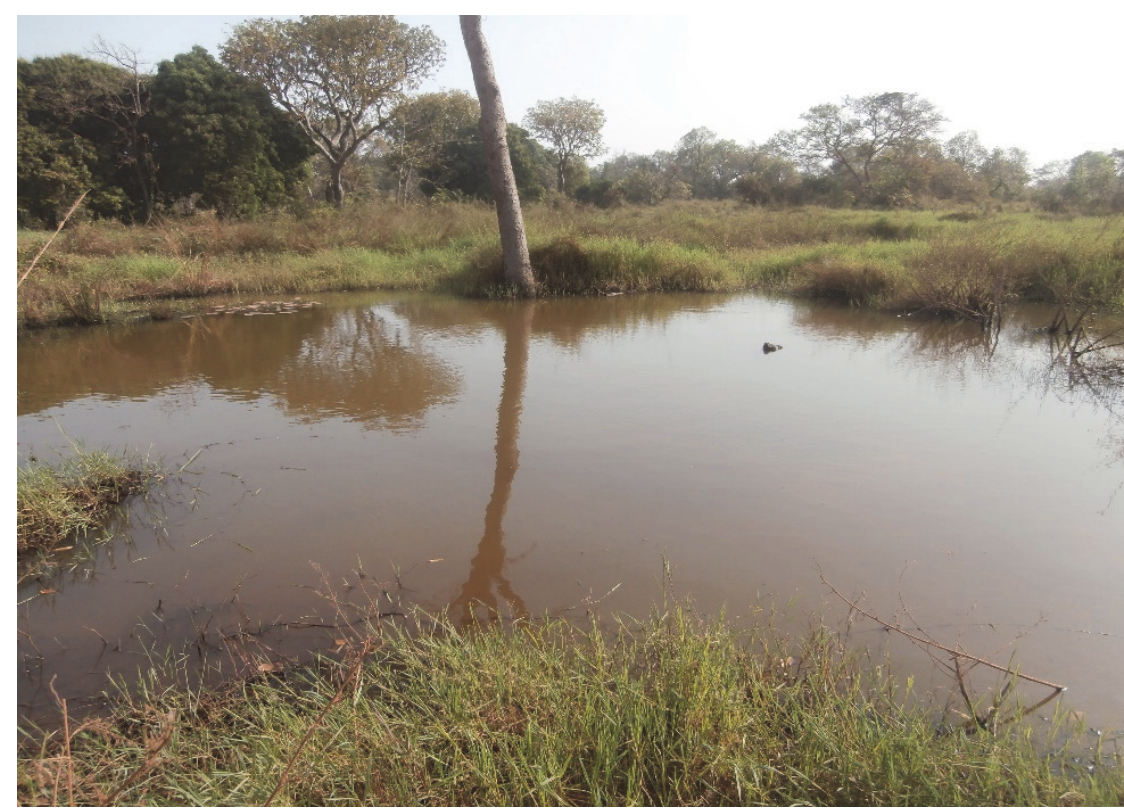

Plate 3. Undisturbed water body and surrounding secondary forest vegetation

\section{Conclusion and Recommendations}

The data analysed showed that most respondents in all districts were of the view that GWD affected the environment. Independent variables that were significantly related to this view were age, occupation of respondents and district. From the responses given it can be said that the GWEP changed people's behaviour towards the disease and influenced former guinea worm endemic communities to practice life styles that transformed their reliance on surface sources of drinking water, thereby improving on community sanitation and vegetation in their communities. Change in peoples' behaviour towards the disease and the environment played a role in breaking the chain of transmission between the disease causing agents (physical environment and biological agent of the disease) and the human host.

Also, the effect of the GWEP on perception towards the environment revealed that opinion leaders, household heads/residents and respondents in all age brackets were generally of the view that good sanitary practices was a major effect of the programme on the environment. This response was evenly distributed between both sexes, with males indicating good sanitation practices and females mentioning tree planting. Respondents with non-formal education were of the view that the effect of the programme on the environment was good sanitation, and all respondents from the Zabzugu-Tatale district indicated that the programme's effect on the environment was the encouragement given to tree planting. With the current need to improve the natural environment as a result of deforestation it is recommended that in carrying out disease eradication programmes, the environmental protection agency should be included in these programmes to educate the populace on the importance of keeping the flora and fauna in ways that would ensure the integrity of the natural and built environment and enhance the overall health status of community members.

\section{References}

Acheampong, S. Y., \& Hess, J. W. (1998). Hydrogeologic and hydyochemical framework of the shallow groundwater system in the southern Voltain Sedimentary Basin. Ghana. Hydrogeology Journal, 6(4), 527537. https://doi.org/10.1007/s100400050169

Brieger, W. R., Otusanya, S., Adeniyi, J. D., Tijani, J., \& Banjoko, M. (1997). Eradicating guinea worm without wells: unrealized hopes of the water decade, 12(4), 354-362. https://doi.org/10.1093/heappol/12.4.354

CDC. (1986). Guinea worm wrap-up no. 12. WHO Collaborating Centre for Research, Training and Control of Dracunculiasis, Atlanta.

CDC. (1987). Guinea worm wrap-up no. 18. WHO Collaborating Centre for Research, Training and Control of Dracunculiasis, Atlanta 
CDC. (1988). Guinea worm wrap-up no. 20. WHO Collaborating Centre for Research, Training and Control of Dracunculiasis, Atlanta

CDC. (1989) Guinea worm wrap-up no. 24. WHO Collaborating Centre for Research, Training and Control of Dracunculiasis, Atlanta

CDC. (1989) Guinea worm wrap-up no. 25. WHO Collaborating Centre for Research, Training and Control of Dracunculiasis, Atlanta

CDC. (1989) Guinea worm wrap-up no. 26. WHO Collaborating Centre for Research, Training and Control of Dracunculiasis, Atlanta

CDC. (1989) Guinea worm wrap-up no.23. WHO Collaborating Centre for Research, Training and Control of Dracunculiasis, Atlanta

CDC. (1990) Guinea worm wrap-up no. 27. WHO Collaborating Centre for Research, Training and Control of Dracunculiasis, Atlanta

Cresswell, J. W. (2009). Research design: qualitative, quantitative, and mixed methods approaches (3rd ed). London: Sage Publications. pp. 194-201

Dean, J. S., Euler, R. C., Gumerman, J., \& Plog, F. (1985). Human Behaviour, Demography, and Paleoenvironment on the Colorado Plateaus. American Antiquity, 50(3), 537-554. Retrieved from https://www.jstor.org./stable/280320

Dietz, T., Geest, K., \& Obeng, F. (2013). Local perceptions of development and change in Northern Ghana. In Yaro, J. (Ed.), Rural development in Northern Ghana. Nova Science Publishers, New York. Pp. 17-36.

Ghana Health Service, (July 2010) Monthly Epidemiological Bulletin, Public Health Division

Ghana Statistical Service [GSS]. (2008-2017). Ghana Population Census 1984. GHA_1984_PHC_VO1_M. Retrieved from www.statsghana.gov.gh

Ghana Statistical Service [GSS]. (2013). 2010 Population and Housing Census Report: Non-Monetary Poverty in Ghana. Accra, Ghana: Ghana Statistical Service.

GHS/GWEP (2012). Ghana Guinea Worm Eradication Programme: Number of Cases - Reported by Region 2009 $-2011$.

Greenwood, B., Greenwood, A., \& Bradley, A. (2017). Guinea worm infection in northern Nigeria: reflections on a disease approaching eradication. Tropical Medicine and International Health, 22(5), 558-566. https://doi.org/10.1111/tmi.12855

Hochkirch, A., Beninde, J., Fischer, M., Krahner, A., Lindemann, C., Matenaa, D., .. \& Veit, M. (2017). License to Kill? Disease Eradication Programs May Not be in Line with the Convention on Biological Diversity. Conservation Letters, 11(1), 1-6. https://doi.org/10.1111/conl.12370

Hopkins, D. R., Ruiz, Tiben, E., Downs, P., Withers, C., \& Maguire, J. H. (2005). Dracunculiasis eradication: The final inch. Am. J. Trop. Med. Hyg., 73(4), 669-675.

Hunter, J. M. (1966). River blindness in Nangodi, Northern Ghana: A hypothesis of cyclical advance and retreat. Geographical Review, 56(3), 398-416. https://www.jstor.org/stable/212464

Hunter, J. M. (2003). Inherited burden of disease: Agricultural dams and the persistence of bloody urine (Schistosomiasis haematobium) in the Upper East Region of Ghana, 1959-1997. Social Science and Medicine, 56, 219-34. https://doi.org/10.1016/S0277-9536(02)00021-7

Hunter, J. M., Rey, L., \& Scott, D. (1982). Man-made lakes and man-made diseases: Towards a policy resolution. Soc. Sci. Med., 16, 1127-1145. Retrieved from 0277-9536/82;1 I I 127-19SO3.OQ O

Krejcie, R. V., \& Morgan, D. W. (1970). Determining sample size for research activities. Educational and Psychological Measurement, 30, 607-610. https://doi.org/10.1177/001316447003000308

Olsen, A., Magnussen, P., \& Anemana, S. (1997). The acceptability and reliability of a polyester drinking water filter in a dracunculiasis-endemic village in Northern Region, Ghana. Bulletin of World Health Organization, 75(5), 449-452.

Tayeh, A., \& Cairncross, S. (2009). Certification of disease eradication: lessons from dracunculiasis. Tropical Medicine and International Health, 14(12), 1-6. https://doi.org/10.1111/j.1365-3156.2009.02393.x

The Carter Centre. (1998-1999). Wagining Peace, Fighting Disease, Building Hope. One Copen Hill, 453 Freedom 
Parkway Atlanta, Georgia 30307 www.cartercenter.org. Retrieved from www.cartercenter.org

The Carter Centre. (2001-2002). Wagining Peace, Fighting Disease, Building Hope. One Copen Hill, 453 Freedom Parkway Atlanta, Georgia 30307 www.cartercenter.org. Retr.ieved from www.cartercenter.org

Waddy, B. B. (1956). Organization and work of the Gold Coast Medical Field Units. Trans. R. Soc. Trop. Med. Hyg., 50, 313-336. https://doi.10.1016/0035-9203(56)90042-6

Weiss, A. J., Vestergaard-Frandsen, T., Ruiz-Tiben, E., Hopkins, D. R., Aseidu-Bekoe, F., \& Agymang, D. (2018). What It Means to Be Guinea Worm Free: An Insider's Account from Ghana's Northern Region. American Journal of Tropical Medicine and Hygiene, 98(5), 1413-1418. https://doi.org/10.4269/ajtmh.17-0558

Yembilah, N. N. (2015). An Analysis of the Guinea Worm Eradication Programme and its effects on Social and Economic Development in the Northern Region of Ghana. Retrieved from ugspace.ug.edu.gh/handle/123456789/21572?

\section{Copyrights}

Copyright for this article is retained by the author(s), with first publication rights granted to the journal.

This is an open-access article distributed under the terms and conditions of the Creative Commons Attribution license (http://creativecommons.org/licenses/by/4.0/). 